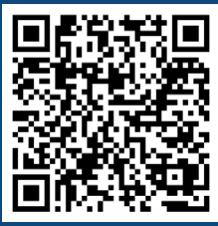

Keywords:

Risk analysis

Financial viability

Historic: Received 06/02/2019 Accepted 01/10/2019

Correspondence: maisarodrigues.eng@gmail.com
Maisa Isabela Rodrigues ${ }^{l a+}$, Álvaro Nogueira de Souza', Maisa Santos Joaquim', Keila Lima Sanches², Juliana Baldan Costa Neves Araújo', Fernando Castanheira Neto', Luiz Moreira Coelho Junior ${ }^{3}$

\title{
FINANCIAL ANALYSIS OF INVESTMENTS IN FOREST CONCESSION FOR AMAZON BRAZILIAN BY DETERMINISTIC AND STOCHASTIC METHODS
}

RODRIGUES, M. I.; SOUZA, A. N.; JOAQUIM, M. S.; SANCHES, K. L.; ARAÚJO, J. B. C. N.; CASTANHEIRA NETO, F; COELHO JUNIOR, L. M. Financial analysis of investments in forest concession for amazon brazilian by deterministic and stochastic methods. CERNE, v. 25, n. 4, p.482-490, 2019.

\section{HIGHLIGHTS}

The forest concession must have a minimum productivity of $17.75 \mathrm{~m}^{3} \cdot \mathrm{ha}^{-1}$.

The NPV of the investment was US\$ 8.04. $\mathrm{m}^{-3}$, the PEB US\$ $0.52 \cdot \mathrm{m}^{-3} \cdot y e a r^{-1}$ and the IRR, $20.7 \%$.

The option of abandoning the investment was exercised in $72.47 \%$ of the analyzes.

The high probability of abandoning highlights a fragility of forest concessions.

\section{ABSTRACT}

Forest concessions were implemented in Brazil as a way to increase the areas of sustainable forest management. Little is known about the financial viability of forest management in Brazil, which is one of its main bottlenecks. In this context, the aim of the study was to evaluate the financial viability of an investment in forest concession. In order to do so, the Net Present Value (NPV), Periodic Equivalent Benefit (PEB), Internal Rate of Return (IRR) and Real Options Analysis (ROA) were adopted, and the option of abandonment was also analyzed. As a variable for ROA analysis, the productivity $\left(\mathrm{m}^{3} \cdot \mathrm{ha}^{-1}\right)$ at the first years of forest concession under study was adopted. The NPV of the investment corresponds to US\$ 8.04. $\mathrm{m}^{-3}$, the PEB was US\$ 0.52. $\mathrm{m}^{-3} \cdot \mathrm{year}^{-1}$ and the IRR, $20.75 \%$. In order to be considered feasible, the forest concession must have a minimum productivity of $17.75 \mathrm{~m}^{3} \cdot \mathrm{ha}^{-1}$. Of the $86 \mathrm{I}$ managerial decisions, the option to proceed with the investment was adopted in 237 nodes (27.53\%), and the decision to abandon was exercised in 624 nodes $(72.47 \%)$. This is a worrying result for the concessionaire companies and also for the management entities of the forest concessions, mainly when comparing with the concessions reality, where abandonment is an option that has been performed. It can be concluded that the high probability of abandoning highlights a fragility of forest concessions. ROA proved to be a good methodology to complement traditional methods of financial analysis, presenting satisfactory results in aiding decision-making. 


\section{INTRODUCTION}

The production of wood logs in the Legal Amazon in the year 2016 amounted to approximately II.4 million cubic meters, concentrated in the states of Pará, Rondônia and Mato Grosso, those been responsible for around $90 \%$ of the total volume produced (IBGE, 2019). Unlike countries like Malaysia and Indonesia, which focuses on the international markets, most of the tropical wood produced in Brazil is self consumed, by civil construction as the main market. Thus, despite being the largest tropical wood producer in the world (ITTO, 20I8), Brazil is not a leader in the international market.

Among the reasons that justify the current position of Brazil in the international market, it is necessary to offer continuous and sustainable wood (Pereira et al., 20I0). For the authors, for continuous supply, low-value primary activities should be replaced by an economy in which forest products and services are valued, and income from activities contributes to improve the quality of life of the local population.

When analyzing the behavior of the international tropical wood market, Silva et al. (2012) pointed to the decline of tropical wood production by Indonesia and Malaysia due to the decrease in the areas that could be used for forest exploitation. For Higuchi et al. (2006), these countries will no longer supply tropical wood to the international market after 2020. The trend in this sector is nomadic, so that, if the forest reserves of the Asian countries are depleted, there will be increased pressure on national forests, since the Amazonian forest consists of the last forest boundaries (Higuchi et al., 2010). Therefore, Brazil will need to have a structure capable of maintaining a continuous demand, and, at the same time, logging must be carried out in a way that does not deplete forest resources.

Forest management consists of a set of planning practices and conservation principles that aim to produce timber and non-timber forest products on an ongoing basis, so that the foresta does not have its resources depleted. In order to expand the areas of sustainable forest management, the management of public forests via forest concession was introduced (Brazil, 2006), in which the management is carried out by private companies, selected through public bidding. In addition to production, forest concessions are designed to prevent cluttered occupation and illegal logging, as well as generating formal employment and income for the local population.

The policy of forest concessions is of manjor importance for the Brazilian forestry sector. This is because Brazil has a vast expanse of forests, with $54.4 \%$ of the territory covered by native or planted forests. There are approximately 270.7 million hectares of federal, state and municipal public forests in the Amazon that can be managed through forest concessions (BFS, 20I7). Given this fact, the State also has the mission to offer timber and non-timber forest products, due to it has large areas.

The lack of information about financial viability is one of the main bottlenecks in forest management. Two of the main researches on forest management in the Brazilian Amazon, in Manaus (INPA) and Tapajós (Embrapa-Cpatu), were carried out on an experimental scale, and no economic studies were developed, which is a gap in this research (Higuchi et al., 2010). The verification of the financial viability of forest concessions can contribute effectively to combine the objectives of maximizing the profit of the companies, and also to minimize the environmental impact of agriculture and livestock, economic alternatives of land use in the region (Santana et al., 20I2).

In view of the above, the present study aimed to evaluate the financial viability of the Jamari National Forest concession through deterministic and stochastic methods.

\section{MATERIAL AND METHODS}

\section{Database}

The database used is the cash flow forecast for the concession of a Forest Management Unit (FMU) located in the Jamari National Forest, state of Rondônia, Brazil. The cost and revenue forecast was elaborated by the concessionaire, which is the basis of its financial planning when participating in the public bidding process.

The study presents a planning horizon of 4 I years, where the first two years consist of pre-exploratory activities, with forestry activity starting from the third year of the contract. According to the company's outline, the FMU was divided into 30 Annual Planning Units (APUs), allowing the exploitation of $25.8 \mathrm{~m}^{3} \cdot \mathrm{ha}$. year ${ }^{-1}$. Thus, the first nine APUs will also be managed in the second cutting cycle.

According to the planning of the concessionaire company, managing the forest at its maximum cutting capacity, the investment presents a cost equivalent to US\$. $\mathrm{m}^{-3}$ and revenues of US\$. $\mathrm{m}^{-3}$. Because it is a forestry concession, there is no acquisition cost of ownership. In this case, there is the royalties cost, which must be paid per unit volume of wood harvested. There are also the costs with the announcement, which must be paid by the concessionaire company. Both costs must be paid to the Brazilian Forest Service (BFS).

\section{Financial Evaluation of the Forestry Concession}

For the financial evaluation of sustainable forest management, the deterministic methods Net Present 
Value (NPV), Periodic Equivalent Benefit (PEB) and Internal Rate of Return (IRR) were adopted. For stochastic analysis, the Real Options Analysis (ROA) (Copeland and Antikarov, 200I) was employed.

\section{Financial evaluation by deterministic methods}

From the cash flow of the investment, the calculations of the NPV, PEB and IRR methods presented below were performed, as quoted by Rezende and Oliveira (2013), where: NPV= Net present value (US\$); $\mathrm{PEB}=$ Periodic Equivalent Benefits; IRR = Internal rate of return; $R j=$ Revenues (US\$); $C j=$ Costs (US\$); = Minimum rate of attractiveness; $j=$ period of time considered (years); $\mathrm{n}=$ Project duration (years).

$N P V=\sum_{j=0}^{n} R_{j}(1+i)^{-j}-\sum_{j=0}^{n} C_{j}(1+i)^{-j}$

$\mathrm{PEB}=\frac{N P V \cdot i \cdot(1+\mathrm{i})^{\mathrm{n}}}{(1+\mathrm{i})^{\mathrm{n}}-1}$

$\operatorname{IRR}=\sum_{\mathrm{j}=0}^{\mathrm{n}} \mathrm{R}_{\mathrm{j}}(1+\mathrm{IRR})^{-\mathrm{j}}-\sum_{\mathrm{j}=0}^{\mathrm{n}} \mathrm{C}_{\mathrm{j}}(1+\mathrm{IRR})^{-\mathrm{j}}=0$

As a discount rate, the $\mathrm{NCPI}$ (National Consumer Price Index) of the initial period of the study (2008) was adopted, which corresponds to $5.9023 \%$, since it is the index used by the BFS to update monetary values of forest concession contract. For decision-making purposes, a constant interest rate was considered, since it is not possible to obtain the index for each period of the planning horizon.

Financial evaluation through the Real Options Analysis

\section{Volatility assessment}

Volatility is calculated based on the rate of return on investment (Copeland and Antikarov, 200I). However, by adopting the rate of return, it would not be possible to analyze the volatility of the two initial investment periods, since revenues start from the third planning horizon period. In addition, the calculation of volatility through the rate of return is not appropriate for this case, since the investment costs and revenues remain unchanged across all periods, which makes it impossible to calculate the volatility. Thus, volatility was calculated for the stochastic variable.

As a source of uncertainty, the wood productivity of the FMU I was adopted. In the absence of a historical productivity series, the Monte Carlo simulation was applied to obtain the random distribution of the variable. Monte Carlo simulation input data (mean and standard deviation) were obtained through the productivity of the first years of forest management (2010 to 2014), with an average of $17.2444 \mathrm{~m}^{3} \cdot \mathrm{ha}^{-1}$, with a standard deviation of 7.3876. With the NVP's distributions generated from the Monte Carlo simulation, the standard deviation (volatility) of the stochastic variable, according to the next equations, In which, where: $\sigma=$ Volatility (\%); $z$ $=$ Forecast variable (US\$); $\overline{\mathrm{Z}}=$ Average of the forecast variable (US\$); $z_{i}=$ Forecast variable at time i (US\$); $N=$ Number of data; In = Neperian logarithm; $P V_{0}=$ Present value at instant (US\$); $P V_{1}=$ Present value at time $t_{1}$ (US\$); $C F_{1}=$ Cash flow at time (US\$).

$\sigma=\sqrt{\frac{\sum_{\mathrm{i}}^{\mathrm{N}}\left(\mathrm{z}_{\mathrm{i}}-\overline{\mathrm{z}}\right)^{2}}{(\mathrm{~N}-1)}}$

$\mathrm{z}=\ln \left(\frac{\mathrm{PV}_{1}}{\mathrm{VP}_{0}}\right)$

$\mathrm{PV}_{0}=\sum_{\mathrm{t}=1}^{\mathrm{T}} \frac{\mathrm{CF}_{\mathrm{t}}}{(1+\mathrm{i})^{\mathrm{t}}}$

$\mathrm{PV}_{1}=\sum_{\mathrm{t}=2}^{\mathrm{T}} \frac{\mathrm{CF}_{\mathrm{t}}}{(1+\mathrm{i})^{\mathrm{t}-1}}$

Event tree

The binomial model of Cox et al. (1979), presented in the following equations, was used to calculate the upward and downward movements of the event tree, as well as their respective probabilities of occurrence. Where: $\mathrm{u}=$ Proportion of upward movement of the event tree; $d=$ Proportion of the downward movement of the event tree; $\mathrm{e}=$ Neperian Logarithm; $\Delta \mathrm{t}=$ Time interval (limited to I); $\mathrm{CF}_{n-1}=$ Cash flow at time $\mathrm{n}^{-1} ; \mathrm{CFu}=$ Upward cash flow; $C D_{f}=$ Downward cash flow; $\mathrm{p}=$ Risk-neutral probability $(\%) ; r_{f}=$ Risk-free interest rate (\%).

$$
\begin{aligned}
& \mathrm{u}=\mathrm{e}^{\sigma \sqrt{\Delta t}} \\
& \mathrm{~d}=\frac{1}{\mathrm{u}} \\
& \mathrm{CF}_{\mathrm{u}}=\mathrm{CF}_{\mathrm{n}-1 \cdot \mathrm{u}} \\
& \mathrm{CF}_{\mathrm{d}}=\mathrm{CF}_{\mathrm{n}-1 \cdot \mathrm{d}} \\
& \mathrm{p}=\frac{\left(1+\mathrm{r}_{\mathrm{f}}\right)-\mathrm{d}}{(\mathrm{u}-\mathrm{d})} \\
& \mathrm{q}=1-\mathrm{p}
\end{aligned}
$$


The NPV of the investment was adopted as the value of the initial period (underlying asset subject to risk) of the event tree. For the second period $(t=n)$, the value of the node at $t=n-I$ was multiplied by the ratio of the upward $(\mathrm{u})$ and downward (d) motions. The same was done for subsequent periods.

\section{Abandonment value}

For the evaluation of the event tree, it was considered the option to abandon the investment when it presented unsatisfactory financial returns, or to continue when the returns were satisfactory. The nodes whose present value was lower than the abandonment value of the period under analysis were considered unsatisfactory. The nodes considered satisfactory were those where the present value of the node was superior to the abandonment value.

As stated in the forest concession contract, in case of abandonment of the investment by the concessionaire company, the assurance will be forfeited, corresponding to US $\$ 414,302$. I0. The abandonment value corresponds to the present value of the machines, equipment and vehicles up to the analyzed period, which can be converted into a possible revenue if the investor decides to abandon the concession. At the residual value, the value of the assurance was subtracted, which represents a cost if this option is exercised. Thus, the exercise price of the abandonment option consists of the balance between the residual value of the machines, vehicles and equipment, minus the contractual termination penalty to be paid upon termination of the contract.

\section{Real Option Analysis}

By assigning value to the managerial decision of the decision tree, one obtains the option tree. The evaluation of the returns of the decision tree was performed by a backward analysis, that is, from the last period $(t=40)$ to the first one $(t=0)$, being the value of the option calculated for each decision tree node.

The calculation of the last period of the option tree was done through Equation I4. In cases where the option of abandonment was exercised, the option value was the result of the subtraction between the option's exercise value and the present value of the analyzed node. When the decision was to continue the investment, zero was adopted for the option value. For the other periods, the option value was calculated according to the neutral risk probability (Equation I5). Where: ROV $=$ Real Option Value (US\$); $X=$ Exercise value of the option (US\$); = Present value in the node of the option tree (US\$); = Return of the option at $\mathrm{t}=\mathrm{n}$; = Return of the upward option at $\mathrm{t}=\mathrm{n}+\mathrm{I}$; = Return of the downward option at $\mathrm{t}=\mathrm{n}+\mathrm{I}$.

$\mathrm{R}_{\mathrm{OV}}=\operatorname{Max}[\mathrm{X}-\mathrm{Pv} ; 0]$
$\mathrm{R}_{0}=\frac{\mathrm{p} \cdot \mathrm{Ru}+(1-\mathrm{p}) \cdot \mathrm{Rd}}{1+\mathrm{i}}$

The value presented in the first period $(t=0)$ of the option tree corresponds to the NPV with flexibility. The difference between the traditional and flexible NPV corresponds to the Real Option Value (VOR), as presented in Equation 16. Where: $\mathrm{NPV}_{\text {exp }}=$ Expanded Net Present Value (US\$); NPV = Net Present Value (US\$); PVO = Present Value of the Option (US\$).

$\mathrm{PVO}=\mathrm{NPV}_{\mathrm{exp}}-\mathrm{NPV}$

\section{RESULTS AND DISCUSSION}

\section{Financial evaluation by deterministic methods}

According to FLONA Jamari's FMU I concession contract, the concessionaire company must pay US\$ $28.91 / \mathrm{m}^{3}$ to BFS. Considering that the other items of the cash flow remain constant, in order for the investment to be considered feasible by deterministic methods, the investment should have a minimum productivity of 17.75 $\mathrm{m}^{3} / \mathrm{ha}$. Contrasting the minimum productivity found with the annual productivity presented in the first years of the forest concession, it can be observed that productivity presented values between $6.6 \mathrm{~m}^{3} \cdot \mathrm{ha}^{-1}$ to $25.1 \mathrm{~m}^{3} \cdot \mathrm{ha}^{-1}$, with an average productivity of $17.2 \mathrm{~m}^{3} \cdot \mathrm{ha}^{-1}$, less than the minimum value found.

The values related to the initial productivity of the concession under study are worrisome, since they make the investment unfeasible. Because it is a tropical forest, the areas are very heterogeneous, as well as the composition of species, which may have contributed to the low productivity observed. In this context, the forest inventory must be rigorously carried out, since errors in estimating the species composition of the area can lead to poor financial results.

The financial evaluation of the investment through deterministic methods presented viability, since the NPV and PEB methods presented positive values. The NPV of the investment corresponds to US\$ $8.04 / \mathrm{m}^{3}$, with a PEB of US\$ $0.52 / \mathrm{m}^{3} /$ year. The IRR of the investment corresponds to $20.75 \%, 3.52$ times greater than the discount rate adopted in the study. Therefore, in order for the investment to be considered feasible, it may present a maximum discount rate of $20.75 \%$. Despite being considered to be financially viable, the result 
presented is insufficient for decision-making, since the risks and managerial flexibility throughout the investment are not considered (Nardeli and Macedo, 20I2), which does not represent the reality of marketplace.

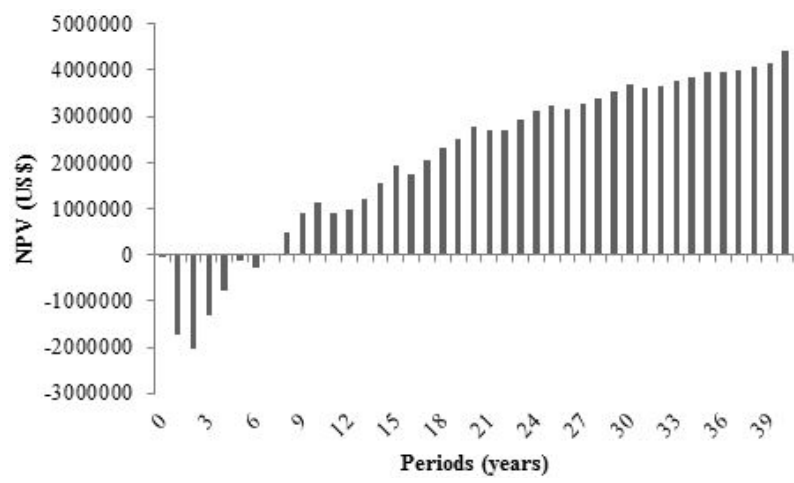

FIGURE I NPV of the investment over the planning horizon.

Due to the high initial costs, the financial return for the first periods of analysis presents negative values. This is because initial investments are necessary to carry out pre-exploratory activities, as well as the costs of machinery and equipment required for forestry activities. Thus, there are a series of costs that must be performed before the extraction of wood, and the revenues only starts with the commercialization of wood, since wood is the only product to be commercialized by the forest concession under study.

In addition to the high initial investment, characteristic of the investments in forest management, the beginning of logging is being carried out late. According to the financial planning adopted for the study, all the pre-exploratory activities and investments required to start the activities should be carried out in the first year of the concession. However, by analyzing the contracts in force until mid-2018, the average time for the beginning of the exploration is over 22 months, ranging from 15 to 28 months.

The objectives of sustainable multiple use of National Forests have not been achieved by forest concessions as they have only exploited the timber product. (Fernandes et al., 2017). The management of non-timber forest products is a bonus criterion foreseen in forest concession contracts, and also consists of a source of revenue that can be exploited in this category of public forest management. The estimates, both quantitative and periodicity, of non-timber forest products, such as chestnut, oil-resin, seeds, among others, with commercial value, should be included in the forest inventory (Nogueira and Rodrigues, 2007), since they can add value to the investment.

Stealing wood species on private lands, indigenous areas and public lands is common in private, indigenous and public areas (Chimeli and Soares, 20I7). In this context, it is believed that forest concessions have played the role of safeguarding the granted areas and preventing illegal logging, as this is one of the policy objectives. Studies indicate that forest concessions have inhibited illegal logging in public areas, once that less than $6 \%$ of public forest invasions occur in forests under forest concession. (Muniz and Pinheiro, 2019).

\section{Financial evaluation through ROA}

\section{Volatility assessment}

The Monte Carlo simulation randomly generated a normal distribution of the stochastic variable (Figure 2). With the random distribution of forest concession productivity, the mean and standard deviation (volatility) of the probability of occurrence of productivity was calculated.

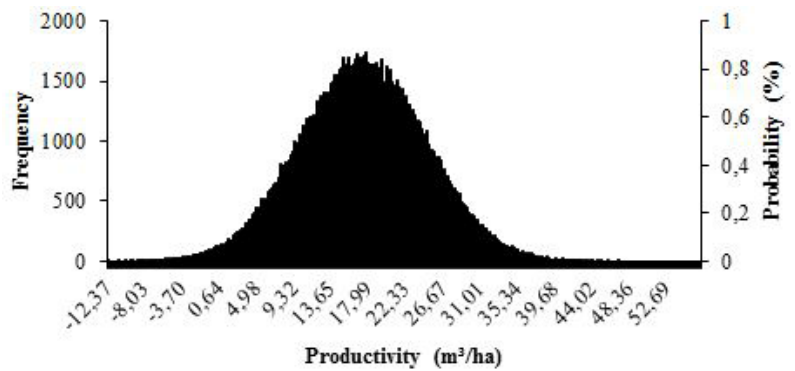

FIGURE 2 Distribution of probability of forest management productivity.

The mean and volatility of the productivity variation were equivalent to 0.00096 and 0.3446 (34.64\%), respectively. Upward and downward movements were equivalent to I. 40 and $0.7 \mathrm{I}$, respectively. It was observed a greater probability of occurrence of the downward movement, corresponding to $76.37 \%$. The probability of occurrence of the upward movement was $26.63 \%$.

\section{Event tree}

By multiplying the NPV by the values of the upward and downward movements, the event tree was obtained, with a total of $86 \mathrm{I}$ nodes. Due to the long duration of the analyzed investment, complete graphical visualization of the event tree, as well as the decision tree and option tree becomes impractical. A representation of the event tree is shown in Figure 3, where the seven initial periods are inserted.

Since the event tree presents binomial disposition, it is not possible to visualize the other values that can occur in the interval between the minimum and the maximum of the variable under study (Joaquim et al., 2015). Without inserting managerial flexibility in the analysis of the event tree, the value obtained corresponds 


\begin{tabular}{|c|c|c|c|c|c|c|c|}
\hline \multicolumn{8}{|c|}{ Periods } \\
\hline 0 & 1 & 2 & 3 & 4 & 5 & 6 & 7 \\
\hline \multirow{12}{*}{8.05} & & & & & & 60.63 & \\
\hline & & & & & 43.31 & & \\
\hline & & & & 30.94 & & 30.94 & \\
\hline & & & 22.10 & & 22.10 & & \\
\hline & & 15.79 & & 15.79 & & 15.79 & \\
\hline & 11.28 & & 11.28 & & 11.28 & & \\
\hline & & 8.05 & & 8.05 & & 8.05 & $\ldots$ \\
\hline & 5.75 & & 5.75 & & 5.75 & & \\
\hline & & 4.11 & & 4.11 & & 4.11 & \\
\hline & & & 2.93 & & 2.93 & & \\
\hline & & & & 2.10 & & 2.10 & \\
\hline & & & & & 1.50 & 1.07 & \\
\hline
\end{tabular}

FIGURE 3 Representation of the investment event tree.

to the NPV initially calculated. As a way to verify that the event tree is correct, one can analyze the values presented in the rows. For each row, the values should be the same, since they are not affected by the volatility (Copeland and Antikarov, 200I).

The longer the analysis period, the greater the range of the event tree values, the greater the investment risk, and the lower the probability of occurrence of the extreme values (Figure 4). The extreme nodes of the last period of the event tree present values between US\$ $5,608,020.35 \cdot \mathrm{m}^{-3}$, and values that tend to zero in the descending movement (US\$ $0.0000 \mathrm{I} / \mathrm{m}^{-3}$ ). For the extreme values to occur, it is necessary that, during the analyzed period, only upward or downward movements occur in the event tree. Regardless of the period analyzed, the highest probability of occurrence is found from the central line (NPV), being $23.63 \%$ for the first upward movement and $76.37 \%$ for the first descending movement. As shown in Figure 4, as it moves away from the center line, its probability of occurrence decreases.

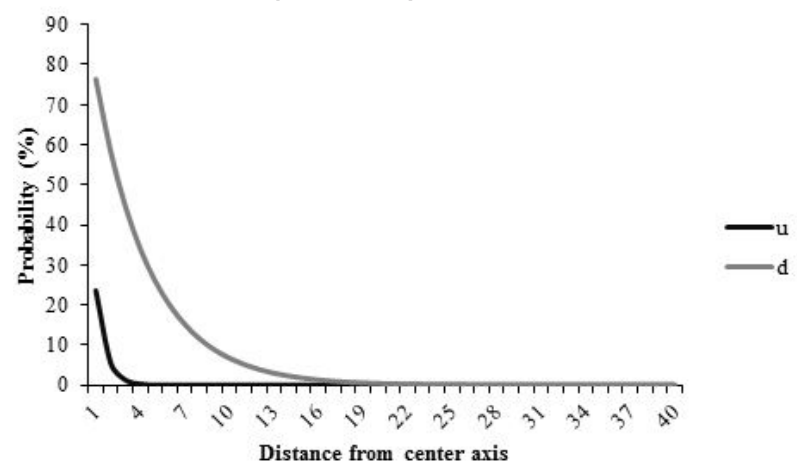

FIGURE 4 Probability of upward and downward movements.

The probability of occurrence of the extreme value of the upward movement corresponds to $8,65,10-26$. The probability of occurrence of the extreme value of the downward movement is 2.08.10 -5. Therefore, it is expected that the end values, both the upper and lower limit, are not reached, so that the values obtained at the end of the project should approximate the value of the underlying asset subject to risk (Copeland and Antikarov, 200I, Souza Neto et al., 2008).
Abandonment Value

In order to maximize return on investment, the option of abandonment allows the investor to exercise the option at any time across the planning horizon. When exercising this option, the investor will obtain the residual value of the investment, which adds value to the project.

The abandonment value was calculated for each period of the investment, considering the same interest rate adopted for the NPV analysis (Figure 5). Since there is no residual value for the investment in the two initial periods, the abandonment value of the investment corresponds to zero. In the last period of the planning horizon, the abandonment value corresponds to US\$335.86. $\mathrm{m}^{-3}$.

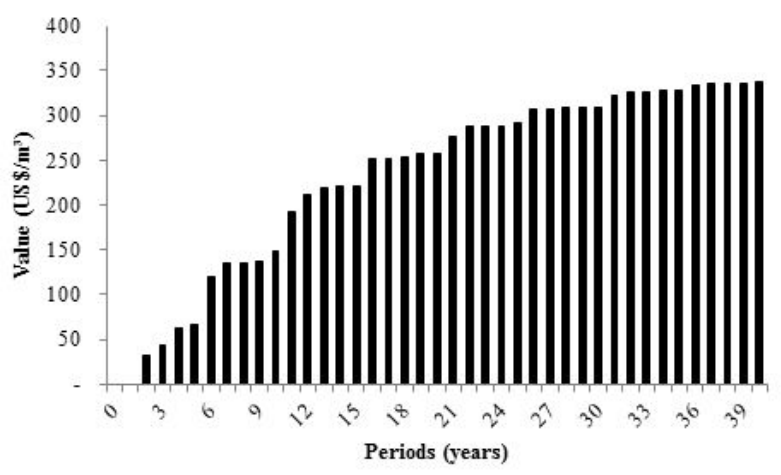

FIGURE 5 Value of the abandon option over the planning horizon.

As shown in Figure 5, the value of the abandon option is lower in the initial investment periods, gradually increasing over the planning horizon. In projects that require investment in all periods of the planning horizon, such as the study investment, the value of abandonment is cumulative and increasing (Joaquim, 20I5).

\section{Real Option Analysis}

When evaluating the event tree, the analysis of the optimal moment to exercise the option is performed, with the objective of maximizing the financial return. The decision to continue or abandon the investment was analyzed by comparing node by node between the abandonment value and the present value of the node of the event tree. Thus, the option exercised depends on which alternative presents the highest expected financial return (Rodrigues et al., 2013). Figure 6 presents a partial view of the decision tree, assembled with management decisions.

Of the $86 \mathrm{I}$ managerial decisions to be taken in the event tree, the option to proceed with the investment was adopted in 237 nodes (27.53\%), and the decision to abandon was exercised in 624 nodes $(72.47 \%)$. Thus, the option to proceed with the investment was exercised only in the nodes where the conditions were considered very 


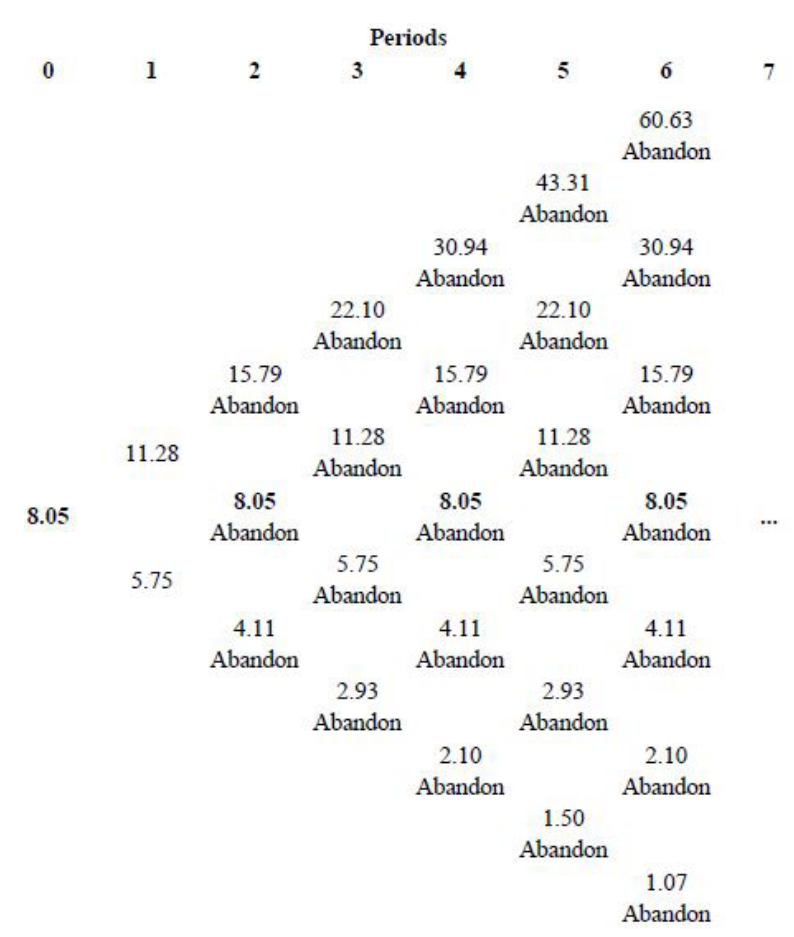

FIGURE 6 Representation of the investment decision tree.

favorable to the investment. The decision tree presents the optimal decisions for the investment. As expected, the abandonment option was exercised when the project presented problems, and the option to continue when the returns were satisfactory (Copeland and Antikarov, 200I).

The high number of choices made in favor of the abandonment of the investment makes evident the fragility of investments in forest concession. The study is based on investor planning data, which led them to choose the investment, and even under ideal conditions, the results of the study showed a high probability of abandoning the investment. This financial fragility presented in the study can be observed in the existing forest concession contracts.

Around the middle of 2018 , about I million hectares were under forest concession (BFS, 2018). Twentyone FMUs were bidden. However, 3 of them were not conceded because there were no companies interested in the investment, so 18 contracts were signed for 40 years. Of these, two were rescinded, one in the seventh period and another in the fourth period. Two other contracts are in default with the BFS (BFS, 2018).

Given the situation presented by the forest concessions in the Brazilian Amazon, the possibility of abandonment should also be considered in the planning of the managing body, since it is in fact a real possibility that has even been exercised. For Azevedo Ramos et al. (2015), the forest concessions are complex and difficult to implement and, despite presenting flaws, the process of Brazilian forest concessions is maturing slowly but steadily. Still, according to the authors, all this effort may be useless if the tropical wood market is flooded with cheaper products, generated from an illegal production.
Illegally harvested timber reaches the market at a lower price than the product from managed areas, so legal timber cannot compete for price with illegally harvested timber. As a way of making timber produced in forest concessions competitive in the market, we must invest in initiatives to combat illegality. For Lima et al. (2018), to ensure long-term effectiveness, the Federal Government must maintain lucrative forest concessions for the investor. In this context, the authors state that embrace planning should be done, including initiatives such as public land designation, land regularization, and incentives for timber trade.

The analysis of managerial flexibility was done through the real option tree (Figure 7), which presents the value of the option for each node. It can be observed that, when considering the real options, there was an increase in the financial return of the investment. By incorporating the abandonment value into the ROA analysis, using the risk-neutral probability methodology, a present value of US\$ 40.48. $\mathrm{m}^{-3}$ was obtained, which corresponds to the value of the abandonment option of the investment, about 5 times larger than the traditional NPV. The high value of the abandonment option is due to the large proportion of the exercise of the option of abandon in the decision tree.

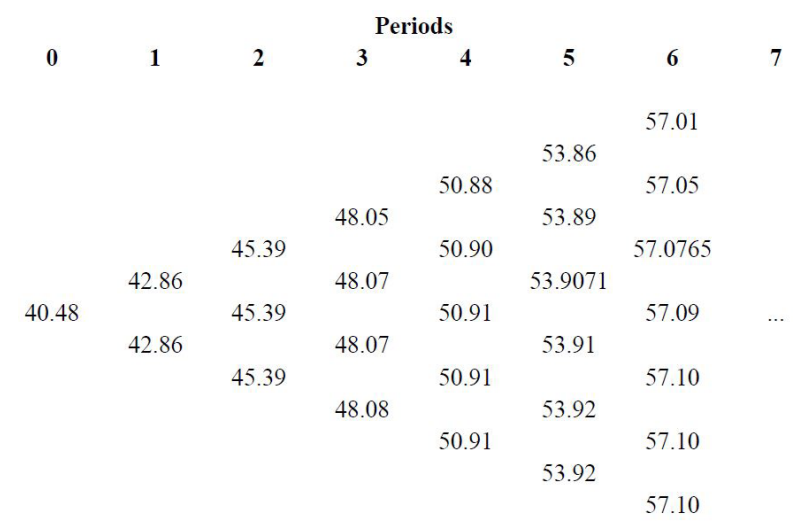

FIGURE 7 Representation of the real investment option tree.

The investment flexibility is positive, and the exercise of the real option created through available managerial flexibility increased the return on investment. This value expresses the managerial flexibility that investors obtain when undertaking the investment (Copeland and Antikarov, 200I). As expected, the financial valuation of the investment by means of deterministic methods presented values inferior to the analysis through ROA. As forest concessions are made in public areas (FLONAs), the results obtained with the ROA method should not be neglected (Moreira et al., 2000, Rocha et al., 2006). Thus, the financial returns of an investment in forest concession given by the ROA method are an important element for the bidding process and for government policies on forest concessions (Rocha et al., 2000). 
In assessing the trend of using ROA to analyze investment decisions in the forest sector, Chaudhari et al. (2016) highlight that the use of the methodology is relatively new and has recently been applied to woodcutting contract situations. According to the authors, the number of studies has been constant since the 2000s, with an average of 2.7 studies published per year. For the authors, although the analysis has attracted attention, discounted cash flow methods remain the main decision support tool for forestry investments.

The wide use of discounted cash flow methods is due to the low complexity and easy application and interpretation of results. In contrast, ROA has a more complex application and needs more consistent assumptions. In the analysis performed in the present study, the stochastic methodology was satisfactory in contrasting the results obtained with the reality shown by the forest concessions.

\section{CONCLUSION}

The option of abandoning the investment was exercised in $72.47 \%$ of the nodes of the option tree. Analyzing the forest concession contracts in force up to the middle of 2018, in case of abandonment and default, it is evident the difficulty of some concessionaires to continue with the investment. The high choice for this option is a worrying fact for the good progress of the forest concessions, and should be considered by both, the investors and the managing body.

\section{REFERENCES}

AZEVEDO-RAMOS, C.; SILVA, J.N.M.; MERRY, F. The evolution of Brazilian forest concessions. Elementa Sci Anth, 2015.

BFS (BRAZILIAN FOREST SERVICE). Concessões florestais. Available at: http://www.florestal.gov.br/processo-deconcessao. Accessed in: 22 July 2018.

BFS (BRAZILIAN FOREST SERVICE). Plano anual de outorga florestal 20I8. v. I2, n. I, 59p., 2017.

BRAZIL. Lei $\mathrm{N}^{\circ}$ II.284, de 02 de março de 2006. Dispõe sobre a gestão de florestas públicas para a produção sustentável. Available at: http://www.planalto.gov.br/ ccivil_03/_ato2004-2006/2006/lei/II I284.htm. Accessed in: 28 July 2018.

CHAUDHARI, U.K.; KANE, M.B.; WETZSTEIN, M.E. The key literature of, and trends in, forestry investment decisions using real options analysis. International Forestry Review. v.18, n.2, p.146-179, 2016.
CHIMELI, A.B.; RODRIGO, R.R. The use of violence in illegal markets: evidence from mahogany trade in the brazilian Amazon. American Economic Journal: Applied Economics. v.9, n.4, p.30-57, 2017.

COPELAND, T.E.; ANTIKAROV, V. Real Options: A Practitioner's Guide. Texere, 200I. 272p.

COX, J.S.; ROSS, S.; RUBINSTEIN, M. Option Pricing: a simplified approach. Journal of Financial Economics. v.7, p.229-263, 1979.

FERNANDES, A.P.D.; HOEFLICH, V.A.; VIANA, G.; AMENDOLA, E.C.; OLIVERIA, F.E.M.; ANSOLIN, R.D. Destination of public forests in Brazil: an analysis of forest concessions. Nativa, v.5, p.497-503, 2017.

HIGUCHI, N.; SANTOS, J.; LIMA, A.J.N.; HIGUCHI, F.G.; SILVA, R.P.; SOUZA, C.A.S.; PINTO, F.R.; TEIXEIRA, L.M.; CARNEIRO, M.C.; SILVA, S.R. Perspectivas do manejo florestal sustentável para a Amazônia brasileira. Hiléia Revista do Direito Ambiental da Amazônia, 2010. Available at: http://www.pos.uea.edu.br/data/ direitoambiental/hileia/2007/8.pdf. Accessed in: 13 September 2018.

HIGUCHI, N.; SANTOS, J.; TEIXEIRA, L.M.; LIMA, A.J.N.; O mercado internacional de madeira tropical está à beira do colapso. SBPN Scientific Journal, v. I, p.33-4I, 2006.

IBGE (INSTITUTO BRASILEIRO DE GEOGRAFIA E ESTATÍ́STICA). Produção da extração vegetal e silvicultura 2016. Available at: https:/www.ibge.gov. br/estatisticas-novoportal/economicas/agricultura-epecuaria/9105-producao-da-extracao-vegetal-e-dasilvicultura.html?=\&t=o-que-e. Accessed in: I J January 2019.

ITTO (INTERNATIONAL TROPICAL TIMBER ORGANIZATION). Annual report 2017. Yokohama, 55p, 2018.

JOAQUIM, M.S.; SOUZA, A.N.; SOUZA, S.N.; PEREIRA, R.S.; ANGELO, H. Aplicação da teoria das opções reais na análise de investimentos em sistemas agroflorestais. Cerne, v.2I, n.3, p.439-447, 2015.

LIMA, L.S.; MERRY, F.; SOARES-FILHO, B.; RODRIGUES, H.O.; DAMACENO, C.S.; BAUCH, M.A. Illegal logging as a disincentive to the establishment of a sustainable forest sector in the Amazon. PLOS ONE. p.I-2I, 2018.

MOREIRA, A.R.B.; REIS, E.J.; ROCHA, K.; CARVALHO, L. A valoração das concessões nas florestas nacionais da Amazônia: uma abordagem com opções reais. Pesquisa e Planejamento Econômico, v.30, p.327-354, 2000.

MUNIZ, T.F; PINHEIRO, A.S.O. Concessão florestal como instrumento para redução de exploração ilegal madeireira em Unidades de Conservação em Rondônia. Revista FAROL. v. 8, n. 8, p. I2I-142, 2019. 
NARDELLI, P.M.; MACEDO, M.A. Análise de um projeto agroindustrial utilizando a teoria de opções reais: a opção de adiamento. Revista de Economia e Sociologia Rural, v.49, p.94I-966, 20II

NOGUEIRA, J.M.; RODRIGUES, A. A. Manual de Valoração Econômica de Florestas Nacionais. Estudo sobre Valoração Econômica de Florestas Nacional: Produtos Madeireiros e Não Madeireiros do Projeto PNUD/ BRA 97/044 - Desenvolvimento Florestal Sustentável. Instituto Brasileiro de Meio Ambiente e Recursos Naturais Renováveis (IBAMA) and Fundação de Tecnologia Florestal e Geo-Processamento (FUNTEC), p.385-393, 2007.

PEREIRA, D.; SANTOS, D.; VEDOVETO, M.; GUIMARÃES, J.; VERÍSSIMO, A. Fatos florestais da Amazônia 2010. Imazon, 2010, 126p.

ROCHA, K.; MOREIRA, A.R.B.; CARVALHO, L.; REIS, E.J. O Valor de Opção das Concessões nas Florestas Nacionais da Amazônia. Instituto de Pesquisa Econômica Aplicada Série Texto para Discussão 737, 2000, 28p.
ROCHA, K.; MOREIRA, A.R.B.; REIS E.J.; CARVALHO, L. The market value of forest concessions in the brazilian Amazon: a real option approach. Forest Policy and Economics. v.8, p.|49-160, 2006.

RODRIGUES, P.H.F;; FERREIRA, V.A.C.; LEMME, C.F; BRANDÃO, L.H.T. Avaliação de empresas start-up por opções reais: o caso do setor de biotecnologia. Gestão \& Produção, v.20, p.5I I-523, 2013.

SANTANA, A.C.; SANTOS, M.A.S.; SANTANA, A.L.; YARED, J.A.G. O valor econômico da extração manejada de madeira no baixo Amazonas, estado do Pará. Revista Árvore. v.36, p.527-536, 2012.

SILVA, L.F.; SILVA, M.L.; CORDEIRO, A.S. Análise do mercado mundial de madeiras tropicais. Revista de Política Agrícola, v.21, n.3, p.48-54, 2012.

SOUZA NETO, J.A.; BERGAMINI JUNIOR, C. OLIVEIRA, V.O. Opções Reais: introdução à teoria e à prática. Qualitymark, 2008, II2p. 